BMJ Paediatrics Open

\title{
Assessment of SARS-CoV-2 infection by Reverse transcription-PCR and serology in the Paris area: a cross- sectional study
}

Robert Cohen, ${ }^{1,2,3,4}$ Camille Jung, ${ }^{2,5}$ Naim Ouldali, ${ }^{3}$ Aurelie Sellam, ${ }^{6}$ Christophe Batard, ${ }^{3}$ Fabienne Cahn-Sellem, ${ }^{4}$ Annie Elbez, ${ }^{3}$ Alain Wollner, ${ }^{3}$ Olivier Romain, ${ }^{3}$ François Corrard, ${ }^{3}$ Said Aberrane, ${ }^{7}$ Nathalie Soismier, ${ }^{7}$ Rita Creidy, ${ }^{7}$ Mounira Smati-Lafarge, ${ }^{7}$ Odile Launay, ${ }^{8}$ Stéphane Béchet, ${ }^{3}$ Emmanuelle Varon, ${ }^{7}$ Corinne Levy (1) $2,3,4,5$

\section{ABSTRACT}

Background Several studies indicated that children seem to be less frequently infected with SARS-CoV-2 and are potentially less contagious than adults. To examine the spread of SARS-CoV-2, we combined both Reverse transcription-PCR testing and serology in children in the most affected region in France, Paris, during the COVID-19 epidemic.

Methods From 14 April 2020 to 12 May 2020, we conducted a cross-sectional, prospective, multicentre study. Healthy controls and pauci-symptomatic children from birth to age 15 years were enrolled by 27 ambulatory paediatricians. A nasopharyngeal swab was taken for detection of SARS-CoV-2 by Reverse transcription-PCR and a microsample of blood for micromethod serology.

Results Among the 605 children, 322 (53.2\%) were asymptomatic and $283(46.8 \%)$ were symptomatic. Reverse transcription-PCR and serology results were positive for $11(1.8 \%)$ and $65(10.7 \%)$ children, respectively, with no significant difference between asymptomatic and pauci-symptomatic children. Only three children were Reverse transcription-PCR-positive without any antibody response detected. The frequency of Reverse transcription-PCR SARS-CoV-2 positivity was significantly higher for children with positive than negative serology results $(12.3 \%$ vs $0.6 \%, p<0.001)$. Contact with a person with confirmed COVID-19 increased the odds of Reverse transcription-PCR positivity (OR 7.8, 95\% $\mathrm{Cl} 1.5$ to 40.7 ) and serology positivity (OR $15.1,95 \% \mathrm{Cl} 6.6$ to 34.6 ). Conclusion In an area heavily affected by COVID-19, after the peak of the first epidemic wave and during the lockdown, the rate of children with Reverse transcriptionPCR SARS-CoV-2 positivity was very low (1.8\%), but that of serology positivity was higher (10.7\%). Most children with positive Reverse transcription-PCR results also had positive serology results.

\section{Trial registration number NCT04318431.}

\section{INTRODUCTION}

Since the beginning of the COVID-19 pandemic, reports from several countries indicated that the disease was less frequently

\section{What is known about the subject?}

At this time, several studies suggested that children are less frequently infected with SARS-CoV-2 and are potentially less contagious than adults.

- Most of the studies were based on Reverse transcription-PCR SARS-CoV-2 testing, without antibody assays.

\section{What this study adds?}

This study combining Reverse transcription-PCR testing and serology assessed the prevalence of SARS-CoV-2 infection in children in an area heavily affected by the COVID-19 pandemic.

> Among a large cohort of children (>600), $11(1.8 \%)$ had positive Reverse transcription-PCR SARSCoV-2 results and $65(10.7 \%)$ had antibodies to SARS-CoV-2.

- The only factor associated with Reverse transcription-PCR SARS-CoV-2 or serology positivity was the presence of a household contact with COVID-19.

reported and less severe in children than in adults. ${ }^{1-3}$ Worldwide, the number of confirmed paediatric cases seems relatively low, and they account for less than $1 \%$ of hospitalised cases and deaths. ${ }^{14}$ Although most COVID-19 cases in children are not severe, serious COVID-19 illness resulting in hospitalisation can occur in this age group, and recently, hyperinflammatory shock, with features similar to atypical Kawasaki disease, was reported in several countries. ${ }^{5-10}$

However, concerns have been raised that children could play an important role in the spread of the disease because community testing has demonstrated a significant 
number of children with or without subclinical symptoms. ${ }^{11}$ Indeed, if as for influenza, children could be the primary drivers of household SARS-CoV-2 transmission, then a silent spread from children who did not alert anyone to their infection could be a serious driver in the dynamics of the epidemic. ${ }^{12}$ On the basis of this prevailing hypothesis, school closures were implemented almost ubiquitously around the world to try to halt the potential spread of COVID-19. ${ }^{13} 14$

However, several studies had already shown that when SARS-CoV-2 infection was suspected (compatible clinical signs, contact with a person with COVID-19), the rate of positive Reverse transcription-PCR SARS-CoV-2 results was lower in children than in adults. ${ }^{1415}$ In contrast, in Reverse transcription-PCR SARS-CoV-2-positive children, the viral load was comparable between children and adults. ${ }^{16}$ Furthermore, one study suggested that children shed infectious SARS-CoV-2. ${ }^{17}$ However, results from a systematic review of household clusters of COVID-19 revealed that only $3 / 31$ clusters were due to a child index case, and a population-based school contact-tracing study found minimal transmission by child or teacher index cases. ${ }^{18}{ }^{19}$ Finally, other studies suggested that children were potentially less contagious than adults, but the design of these studies does not exclude the possibility of children being more contagious than adults. ${ }^{160-22}$

Some countries such as South Korea and Iceland have implemented widespread community testing. Both countries found children significantly under-represented in cases. In Iceland, this was true in targeted testing of highrisk groups as compared with adults $(6.7 \%<10$ years vs $13.7 \% \geq 10$ years positive cases), and in (invited) population screening, no child $<10$ years old was positive for SARS-CoV-2 as compared with $0.8 \%$ in the general population. $^{23}$

Of note, all these studies were based on Reverse transcription-PCR testing, but serology diagnosis is also an important tool to understand the prevalence and burden of COVID-19. ${ }^{24}$ A serology survey tested adolescents in a high school in the north of France, the site of a cluster at the end of February. Of the 242 students tested, 2.7\% of children $\leq 14$ years old and $40 \%$ aged 15-17 years had positive SARS-CoV-2 serology results ( $\operatorname{IgG}$ ), which suggests a difference in susceptibility to SARS-CoV-2 among younger children. ${ }^{25}$

To best approach the prevalence of SARS-CoV-2 in children at a population level, we combined both Reverse transcription-PCR testing for SARS-CoV-2 and serology in asymptomatic or pauci-symptomatic children (with mild clinical symptoms) in the Paris area, the most affected region in France, during the COVID-19 epidemic.

\section{PATIENTS AND METHODS}

\section{Study population}

This was a cross-sectional prospective, multicentre study conducted by the Association Clinique et Thérapeutique Infantile du Val de Marne network, a research unit expert in epidemiological surveillance and clinical studies in ambulatory paediatric infectious diseases, and the University Intercommunal Créteil Hospital. ${ }^{26}$ Primary care paediatricians $(\mathrm{n}=27)$ took part in the study from 14 April 2020 to 12 May 2020. The strategy of closing schools and the lockdown decided by the French government for the whole country started on 17 March and finished on 11 May 2020.

This study aimed to enrol children from birth to 15 years old who were consulting an ambulatory paediatrician and distributed in two groups: asymptomatic and pauci-symptomatic. Asymptomatic children were defined as children without any symptoms or signs suggesting infectious disease during the previous 7 days. They usually came for vaccination visits. In this group, we defined two subgroups of children: those previously symptomatic (fever, respiratory or digestive symptoms) between 7 days and 2 months before enrolment, and those without any previous symptoms. Pauci-symptomatic children were defined as those with fever isolated or associated with respiratory signs, such as cough, dysphagia, rhinorrhoea, diarrhoea, vomiting, cutaneous signs, taste loss and/ or anosmia during the previous 7 days. Children were excluded if the clinical condition at enrolment required transfer to a paediatric emergency unit or hospitalisation.

After informing the parents of the participating children and obtaining their signed consent, an electronic case report form (eCRF) was completed by the paediatrician to collect sociodemographic data, history, contact with a person with confirmed COVID-19 by Reverse transcription-PCR for SARS-CoV-2, clinical symptoms and signs and additional positive biological tests. We also collected suspected COVID-19 contacts because of the limited availability of testing. Indeed, during the lockdown, the diagnostic Reverse transcription-PCR SARS-CoV-2 test was mainly available for patients with severe disease and/or healthcare workers, and all symptomatic individuals could not be tested. For all enrolled children, during the same visit, a nasopharyngeal (NP) swab was taken for Reverse transcription-PCR detection of SARS-CoV-2 and a microsample of blood for micromethod serology.

\section{Power calculation}

To have an appropriate proportion of confirmed Reverse transcription-PCR SARS-CoV-2-positive patients among asymptomatic and pauci-symptomatic children, with a $95 \% \mathrm{CI}$ of $\pm 3 \%$, assuming a positivity proportion of $<10 \%$, which was the rate of positive Reverse transcription-PCR before the beginning of the study, we needed to enrol 300 children per group (asymptomatic and pauci-symptomatic), for 600 patients in total. 


\section{Serology}

As previously reported, ${ }^{27}$ paediatricians collected fingerstick whole-blood specimens and used the Biosynex COVID-19 BSS test, which was among those approved by the French National Health Authority. ${ }^{27}$ A positive serology result meant that the patient had a previous SARS-CoV-2 infection: positive for IgG or IgM or both. A serology result was considered negative if results for both $\operatorname{IgM}$ and $\operatorname{IgG}$ were negative.

\section{SARS-CoV-2 RT-PCR}

As previously reported, ${ }^{27}$ paediatricians collected NP specimens transported to the centralised microbiology laboratory (CHIC) for the Reverse transcription-PCR for SARS-CoV-2 analysis. NP samples were considered positive with a cycle threshold $(\mathrm{Ct})$ value of $<40$ obtained for any gene. Amplification of two or three targets indicated that SARS-CoV-2 RNA was detected, and amplification of only one target with Ct value of $<38$ indicated a presumptive positive result. We defined as weakly positive any result with Ct values of $>38$ and $<40$. A sample was considered negative if the internal control was amplified but not the viral target genes. A sample was considered invalid when no amplification was obtained for the internal control.

\section{Statistical analysis}

Data were entered by using the eCRF (PHP/MySQL) and analysed by using STATA/SE V.5. For the initial analysis (univariate), quantitative data were compared by Student t-test and categorical data by $\chi^{2}$ or Fisher exact test. Variables (age, clinical signs, contact, siblings and daycare attendance modalities) with $p$ values of $<0.20$ on univariate analysis were included in the multivariable model. For this model, we used a logistic regression to estimate ORs and 95\% CIs for factors associated with Reverse transcription-PCR SARS-CoV-2 and serology positivity. Only variables with $p$ values of $<0.05$ were kept in the final model. All tests were two-sided and were considered significant at a $p$ value of $<0.05$.

The study was registered at ClinicalTrials.gov.

\section{Patient and public involvement}

There were no patients or public involved in the research design, process and research findings dissemination.

\section{RESULTS}

From 14 April 2020 to 12 May 2020, 27 ambulatory paediatricians in the Paris area enrolled 605 children: 322 $(53.2 \%)$ children were asymptomatic and 283 (46.8\%) were pauci-symptomatic. Table 1 presents the characteristics of the enrolled children by group. In the paucisymptomatic group, the main signs and symptoms were fever $(187,66.3 \%)$, cough $(143,50.7 \%)$, pharyngitis $(143$, $50.7 \%)$, rhinitis $(137,48.4 \%)$, diarrhoea $(81,28.7 \%)$, rash $(64,23.0 \%)$, vomiting $(52,18.8 \%)$, dysgeusia $(8$, $3.0 \%)$ and anosmia $(5,3.3 \%)$.

Figure 1 presents the dates of the lockdown and the number of children enrolled, by week, during the first epidemic wave in Paris. ${ }^{28}$

Reverse transcription-PCR SARS-CoV-2 results were positive for $11(1.8 \%)$ children, with no significant difference between children with and without symptoms $\left(\chi^{2}\right.$, $\mathrm{p}=0.3$, table 2 ). The online supplemental table 1 shows the details of the 11 positive Reverse transcription-PCR SARS-CoV-2 cases. Only three children had Reverse transcription-PCR SARS-CoV-2 positivity with a Ct value of $<31$.

On multivariable analysis (online supplemental table 2), contact with a person with proven COVID-19 was the only significant risk factor for Reverse transcription-PCR SARS-CoV-2 positivity (OR 7.8, 95\% CI 1.5 to 40.7).

Table 2 shows the serology results by group. The age distribution of children was similar whatever the serology results, negative or positive: $<3$ months, $1.3 \%$ vs $1.5 \%$; $3-30$ months, $37.2 \%$ vs $26.2 \%$; 31 months -5 years, $29.6 \%$ vs $36.9 \%$; $6-10$ years, $21.7 \%$ vs $26.2 \%$; $\geq 11$ years, $10.2 \%$ vs $9.2 \%$. Serology was positive for 65 of 605 (10.7\%) children, and among these, $87.3 \%$ had a confirmed or suspected contact. Children previously symptomatic during the preceding weeks were more frequently positive on serology.

Reverse transcription-PCR SARS-CoV-2 was more frequently positive for children with positive than negative serology results $(12.3 \%$ vs $0.6 \%, \mathrm{p}<0.001)$. Only three children had Reverse transcription-PCR SARS-CoV-2 positivity without any antibody response detected.

Table 3 shows serology and Reverse transcription-PCR SARS-CoV-2 results for the 543 enrolled children according to contact with a person (adult or child) with suspected or confirmed COVID-19. Only 2 of 275 (0.7\%) children without any contact with a person with COVID-19 had positive Reverse transcription-PCR SARS-CoV-2 results. On multivariable analysis (online supplemental table 3), serology positivity was associated with contact with a person with proven or suspected COVID-19 (OR $15.1,95 \%$ CI 6.6 to 34.6 , and 5.8, 95\% CI 2.6 to 13.2 ).

\section{DISCUSSION}

This study combines Reverse transcription-PCR SARS-CoV-2 and serology results to assess the prevalence of SARS-CoV-2 infection in a large cohort of children in the community. In a region strongly affected by the epidemic (Paris area), during the lockdown, as expected, very few children $(1.8 \%)$ had Reverse transcription-PCR SARS-CoV-2 positivity, but the proportion with serology positivity $(10.7 \%)$ was relatively high. Despite the relatively large number of children included $(>600)$, we did not find a significant difference in rate of positive Reverse transcription-PCR or serology results between asymptomatic and pauci-symptomatic children, which 
Table 1 Characteristics of children enrolled in the study and by pauci-symptomatic and asymptomatic groups

\begin{tabular}{|c|c|c|c|c|c|c|}
\hline & \multirow[b]{2}{*}{$\begin{array}{l}\text { Overall, } \\
\mathrm{N}=605\end{array}$} & \multirow[b]{2}{*}{$\begin{array}{l}\text { Pauci-symptomatic } \\
\text { children, }{ }^{*} n=283\end{array}$} & \multicolumn{3}{|c|}{ Asymptomatic children } & \multirow[b]{2}{*}{$P$ value } \\
\hline & & & $\begin{array}{l}\text { Previously } \\
\text { symptomatic } \\
\text { (>7 days), } ¥ n=118\end{array}$ & $\begin{array}{l}\text { No previous } \\
\text { symptoms,§ } \\
n=204\end{array}$ & Total, $\mathrm{n}=322$ & \\
\hline Age (years) & & & & & & 0.08 \\
\hline Mean \pm SD & $4.9 \pm 3.9$ & $4.8 \pm 3.7$ & $5.6 \pm 4.3$ & $4.7 \pm 4.1$ & $5.0 \pm 4.2$ & 0.1 \\
\hline Median & 3.8 & 4.0 & 4.4 & 3.4 & 3.7 & \\
\hline$<3$ months & $8(1.3)$ & $6(2.1)$ & 0 & $2(1.0)$ & $2(0.6)$ & \\
\hline 3-30 months & $218(36.0)$ & $98(34.6)$ & $37(31.4)$ & $83(40.7)$ & $120(37.3)$ & \\
\hline 31 months -5 years & $184(30.4)$ & $96(33.9)$ & $34(28.8)$ & $54(26.5)$ & $88(27.3)$ & \\
\hline $6-10$ years & $134(22.2)$ & $61(21.6)$ & $29(24.6)$ & $44(21.6)$ & $73(22.7)$ & \\
\hline$\geq 11$ years & $61(10.1)$ & $22(7.8)$ & $18(15.2)$ & $21(10.3)$ & $39(12.1)$ & \\
\hline Sex, male & $322(53.2)$ & $152(53.7)$ & $65(55.1)$ & $105(51.5)$ & $170(52.8)$ & 0.8 \\
\hline $\begin{array}{l}\text { Daycare attendance } \\
\text { before lockdown }\end{array}$ & & & & & & 0.031 \\
\hline Home & $78(13.8)$ & $34(13.0)$ & $6(5.4)$ & $38(19.7)$ & $44(14.5)$ & \\
\hline Childminder & $55(9.7)$ & $24(9.2)$ & $10(9.0)$ & $21(10.9)$ & $31(10.2)$ & \\
\hline Daycare centre & 135 (23.9) & $66(25.2)$ & $29(26.1)$ & $40(20.7)$ & $69(22.7)$ & \\
\hline School & $298(52.7)$ & $138(52.7)$ & $66(59.5)$ & $94(48.7)$ & $160(52.6)$ & \\
\hline Comorbidities & $93(15.4)$ & 45 (15.9) & $28(23.7)$ & $20(9.8)$ & 48 (14.9) & 0.004 \\
\hline Prematurity & $35(6.3)$ & $15(5.7)$ & $7(6.1)$ & $13(7.4)$ & $20(6.9)$ & 0.8 \\
\hline Siblings & & & & & & 0.3 \\
\hline 0 & 115 (20.6) & 57 (21.9) & $18(15.9)$ & $40(21.5)$ & $58(19.4)$ & \\
\hline 1 & $282(50.5)$ & 136 (52.3) & $61(54.0)$ & $85(45.7)$ & $146(48.8)$ & \\
\hline$\geq 2$ & 162 (29.0) & $67(25.8)$ & $34(30.1)$ & $61(32.8)$ & 95 (31.8) & \\
\hline
\end{tabular}

Data are $\mathrm{n}(\%)$ unless indicated.

*Pauci-symptomatic children were those with fever isolated or associated with respiratory signs, such as cough, dysphagia, rhinorrhoea, diarrhoea, vomiting, rash, dysgeusia and/or anosmia, during the previous 7 days.

†P value compares symptomatic children, asymptomatic children previously symptomatic for $>7$ days and asymptomatic children without previous symptoms.

‡Previously symptomatic (fever or respiratory or digestive) between 7 days and 2 months before enrolment.

$\S N o$ previous symptoms.

suggests that most children were asymptomatic after a SARS-CoV-2 infection.

Among asymptomatic children, those with no history of symptoms during the preceding weeks accounted for twothirds of children with positive serology results (28/41), which supports the fact that asymptomatic infections are frequent in children. By contrast, history of symptoms during the preceding weeks significantly increased the risk of positive serology. However, on multivariable analysis, the only factor influencing the positivity of Reverse transcription-PCR or serology was the household contact who previously presented symptoms suggesting COVID19. Of note, the number of siblings in the family did not significantly increase the probability of a positive Reverse transcription-PCR or serology result. Several studies have shown that children were usually infected by an adult in the family. ${ }^{18222930}$ In our study, the importance of familial contagion in the modalities of SARS-Cov-2 transmission is suggested by a very low Reverse transcription-PCR $(0.7 \%)$ and serology $(3.6 \%)$ positivity rate for children without an infected relative and in a period of lockdown.

Among the children with Reverse transcription-PCR positivity $(n=11)$, only three had no antibody response, and eight were positive for IgG with or without IgM positivity. This finding supports that for these three patients, infection had probably occurred some time before enrolment.

We highlight that the frequency of Reverse transcription-PCR SARS-CoV-2 positivity was significantly higher in children with positive than negative serology results (12.3\% vs $0.6 \%, \mathrm{p}<0.001)$. This finding highlights the difficulties in interpreting the significance of a positive Reverse transcription-PCR SARS-CoV-2 result without concomitant antibody testing after the epidemic wave. Preliminary reports suggest that children with Reverse transcription-PCR SARS-CoV-2 positivity and IgG positivity probably had little or no infectivity. ${ }^{31} 32$ In a study of nine patients, attempts to isolate the virus in culture 


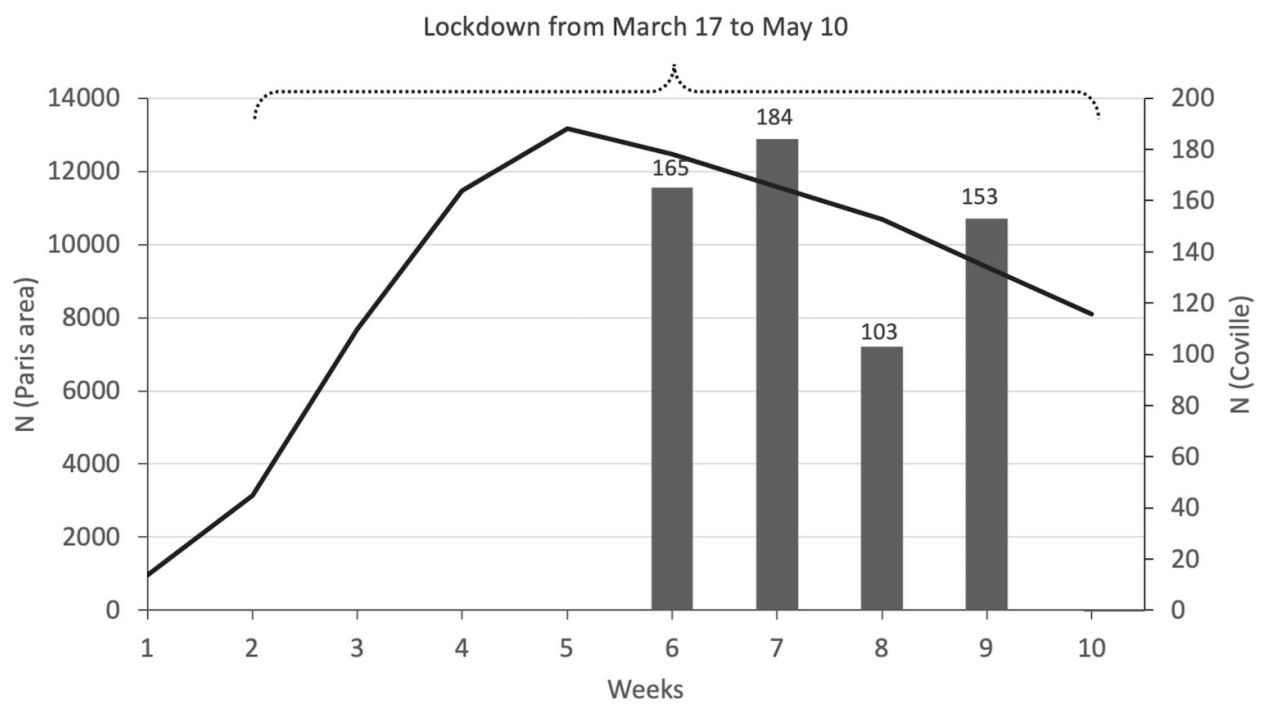

Figure 1 Number of children enrolled and total hospitalisation during the first COVID-19 epidemic wave in the Paris area.

were not successful beyond day 8 of illness onset, which could be related to the decreased infectivity beyond the first week. ${ }^{33}$ In the study of Bullard et al, SARS-CoV-2
Vero cell infectivity was observed with only Reverse transcription-PCR Ct value of $<24$ and symptom onset to test duration of $<8$ days. ${ }^{34}$ Infectivity was likely low for 8 of

Table 2 Results of Reverse transcription-PCR SARS-CoV-2 testing and serology in children by pauci-symptomatic and asymptomatic groups

\begin{tabular}{|c|c|c|c|c|c|}
\hline & \multirow[b]{2}{*}{$\begin{array}{l}\text { Overall, } \\
\mathrm{N}=605\end{array}$} & \multirow[b]{2}{*}{$\begin{array}{l}\text { Pauci- } \\
\text { symptomatic } \\
\text { children, }{ }^{*} n=283\end{array}$} & \multicolumn{3}{|c|}{ Asymptomatic children } \\
\hline & & & $\begin{array}{l}\text { Previously } \\
\text { symptomatic (>7 } \\
\text { days), } \dagger n=118\end{array}$ & $\begin{array}{l}\text { No previous } \\
\text { symptoms,§ } \\
\mathrm{n}=204\end{array}$ & Total, $\mathrm{n}=322$ \\
\hline \multicolumn{6}{|l|}{$\begin{array}{l}\text { Reverse transcription- } \\
\text { PCR }\end{array}$} \\
\hline Overall & $\begin{array}{l}11(1.8) \\
(0.9 \text { to } 3.2)\end{array}$ & $\begin{array}{l}7(2.5) \\
(1.0 \text { to } 5.0)\end{array}$ & $\begin{array}{l}1(0.8) \\
(0.0 \text { to } 4.6)\end{array}$ & $\begin{array}{l}3(1.5) \\
\text { (0.3 to } 4.2)\end{array}$ & $\begin{array}{l}4(1.2) \\
\text { (0.3 to } 3.1)\end{array}$ \\
\hline Definitely positiveł & 5 & 3 & 0 & 2 & 2 \\
\hline Weakly positiveף & 1 & 1 & 0 & 0 & 0 \\
\hline Presumptive $^{\star \star}$ & 5 & 3 & 1 & 1 & 2 \\
\hline \multicolumn{6}{|l|}{ Serology } \\
\hline $\lg M+$ and/or lgG+ & $\begin{array}{l}65(10.7) \\
(8.4 \text { to } 13.5)\end{array}$ & $\begin{array}{l}24(8.5) \\
(5.5 \text { to } 12.4)\end{array}$ & $\begin{array}{l}28(23.7) \ddagger \\
(16.4 \text { to } 32.4)\end{array}$ & $\begin{array}{l}13(6.4) \ddagger \\
\text { (3.4 to } 10.7)\end{array}$ & $\begin{array}{l}41(12.7) \\
(9.3 \text { to } 16.9)\end{array}$ \\
\hline $\lg M+\lg G-$ & $\begin{array}{l}7(1.2) \\
(0.5 \text { to } 2.4)\end{array}$ & $\begin{array}{l}4(1.4) \\
(0.4 \text { to } 3.6)\end{array}$ & $\begin{array}{l}2(1.7) \\
(0.2 \text { to } 6.0)\end{array}$ & $\begin{array}{l}1(0.5) \\
(0.0 \text { to } 2.7)\end{array}$ & $\begin{array}{l}3(0.9) \\
(0.2 \text { to } 2.7)\end{array}$ \\
\hline $\lg M+\lg G+$ & $\begin{array}{l}32(5.3) \\
\text { (3.6 to } 7.4)\end{array}$ & $\begin{array}{l}12(4.2) \\
\text { (2.2 to } 7.3)\end{array}$ & $\begin{array}{l}17(14.4) \ddagger \\
(8.6 \text { to } 22.1)\end{array}$ & $\begin{array}{l}3(1.5) \neq \\
\text { (0.3 to } 4.2)\end{array}$ & $\begin{array}{l}20(6.2) \\
\text { (3.8 to } 9.4)\end{array}$ \\
\hline $\lg M-\lg G+$ & $\begin{array}{l}26(4.2) \\
(2.8 \text { to } 6.2)\end{array}$ & $\begin{array}{l}8(2.8) \\
(1.2 \text { to } 5.5)\end{array}$ & $\begin{array}{l}9(7.6) \\
\text { (3.5 to } 14.0)\end{array}$ & $\begin{array}{l}9(4.4) \\
(2.0 \text { to } 8.2)\end{array}$ & $\begin{array}{l}18(5.6) \\
\text { (3.3 to } 8.7)\end{array}$ \\
\hline
\end{tabular}

Data are $\mathrm{n}(\%)(95 \% \mathrm{Cl})$.

${ }^{*}$ Pauci-symptomatic children were those with fever isolated or associated with respiratory signs such as cough, dysphagia, rhinorrhoea, diarrhoea, vomiting, rash, dysgeusia and/or anosmia, during the previous 7 days.

†Previously symptomatic (fever or respiratory or digestive) between 7 days and 2 months before enrolment.

‡Definitey positive: Ct value $<38$ obtained for two or three genes.

$\S$ No previous symptoms.

TWeakly positive: any result with a Ct value of $>38$ and $<40$.

** Presumptive: $\mathrm{Ct}<38$ obtained for only one target.

$\mathrm{Ct}$, cycle threshold. 
Table 3 Serology and Reverse transcription-PCR results for the 543 enrolled children according to contact with a person (adult or child) with confirmed and/or suspected COVID-19

\begin{tabular}{|c|c|c|c|c|c|}
\hline & \multicolumn{5}{|c|}{ Enrolled children } \\
\hline & Overall, $N=543^{*}$ & $\begin{array}{l}\text { Positive } \\
\text { serology, } n=63\end{array}$ & $\begin{array}{l}\text { Negative } \\
\text { serology, } n=480\end{array}$ & $\begin{array}{l}\text { Positive } \\
\text { Reverse } \\
\text { transcription- } \\
\text { PCR SARS- } \\
\text { CoV-2, } \\
\mathrm{n}=11\end{array}$ & $\begin{array}{l}\text { Negative } \\
\text { Reverse } \\
\text { transcription-PCR } \\
\text { SARS-CoV-2, } \\
\mathrm{n}=532\end{array}$ \\
\hline \multicolumn{6}{|l|}{ Contact } \\
\hline Confirmed COVID-19† & $\begin{array}{l}93(17.1) \\
(14.1 \text { to } 20.6)\end{array}$ & $\begin{array}{l}29(31.2) \\
(22.0 \text { to } 41.6)\end{array}$ & $\begin{array}{l}64(68.8) \\
(58.4 \text { to } 78.0)\end{array}$ & $\begin{array}{l}5(5.4) \\
(1.8 \text { to } 12.1)\end{array}$ & $\begin{array}{l}88(94.6) \\
(87.9 \text { to } 98.2)\end{array}$ \\
\hline Suspected COVID-19‡ & $\begin{array}{l}175(32.2) \\
(28.3 \text { to } 36.3)\end{array}$ & $\begin{array}{l}26(14.9) \\
(9.9 \text { to } 21.0)\end{array}$ & $\begin{array}{l}149(85.1)(79.0 \\
\text { to } 90.0)\end{array}$ & $\begin{array}{l}4(2.3) \\
(0.6 \text { to } 5.7)\end{array}$ & $\begin{array}{l}171(97.7) \\
(94.3 \text { to } 99.4)\end{array}$ \\
\hline $\begin{array}{l}\text { Confirmed/suspected } \\
\text { COVID-19 }\end{array}$ & $\begin{array}{l}268(49.4) \\
(45.1 \text { to } 53.6)\end{array}$ & $\begin{array}{l}55(20.5) \\
(15.9 \text { to } 25.9)\end{array}$ & $\begin{array}{l}213(79.5) \\
(74.1 \text { to } 84.1)\end{array}$ & $\begin{array}{l}9(3.4) \\
(1.5 \text { to } 6.3)\end{array}$ & $\begin{array}{l}259(96.6) \\
(93.7 \text { to } 98.5)\end{array}$ \\
\hline No contact & $\begin{array}{l}275(50.6) \\
(46.4 \text { to } 54.9)\end{array}$ & $\begin{array}{l}8(2.9) \\
(1.3 \text { to } 5.7)\end{array}$ & $\begin{array}{l}267(97.1)(94.3 \\
\text { to } 98.7)\end{array}$ & $\begin{array}{l}2(0.7) \\
(0.1 \text { to } 2.6)\end{array}$ & $\begin{array}{l}273(99.3) \\
\text { (97.4 to } 99.9)\end{array}$ \\
\hline
\end{tabular}

Data are $\mathrm{n}(\%)(95 \% \mathrm{Cl})$.

*543 available data among 605 enrolled patients.

†Confirmed by Reverse transcription-PCR SARS-CoV-2.

¥Suspected symptoms suggestive of COVID-19 because of the limited availability of testing.

the 11 Reverse transcription-PCR SARS-CoV-2-positive children. Indeed, only three children had a Ct value of $<31$.

Our study has several limitations. First, the role of assumed household transmission has probably been overestimated because of the well-followed lockdown in France. ${ }^{35}$ Indeed, more than $86.5 \%$ of children with Reverse transcription-PCR SARS-CoV-2 or serology positivity had a confirmed or suspected COVID-19 household contact. However, our rate of positive serology for children in the Paris area was similar to the rate observed for hospitalised children (11.7\%) and school children $(8.8 \%) .{ }^{22}{ }^{36}$ Second, the ability to successfully collect NP swabs properly could be more difficult in young children and could significantly affect the results and be a factor contributing to the low Reverse transcription-PCR positivity prevalence observed in our population. However, the paediatricians who performed the study were all involved for many years in a pneumococcal NP carriage study (started in 2001 and currently ongoing) and were particularly well trained to collect appropriate NP samples. ${ }^{37}$

School closure or limitation (reduced number of students or days of attendance) has a major impact on children's development and access to learning. ${ }^{38}$ Therefore, the usefulness of school closure or limitation needs evaluation in controlling the COVID-19 epidemic. ${ }^{39}$ We plan to renew this study after the full reopening of schools and daycare centres in the Paris area. To better assess the transmission of SARS-CoV-2 in children and to elucidate their role in the transmission, serial testing of all household members is needed.
Author affiliations

${ }^{1}$ Paediatric Department, Centre Hospitalier Intercommunal de Créteil, Creteil, Îlede-France, France

${ }^{2}$ Université Paris Est, IMRB-GRC GEMINI, Créteil, France

${ }^{3}$ ACTIV, Creteil, France

${ }^{4} \mathrm{AFPA}$, Paris, France

${ }^{5}$ Centre Hospitalier Intercommunal de Creteil, Creteil, Île-de-France, France

${ }^{6}$ Seine Saint Denis, Hôpital Jean Verdier, Bondy, France

${ }^{7}$ Microbiology, Centre Hospitalier Intercommunal de Créteil, Creteil, Île-de-France, France

${ }^{8}$ Hôpital Cochin, Paris, Île-de-France, France

Acknowledgements We are grateful to the investigators of the COVILLE study Network: Akou'ou M.H, Auvrignon A, Belaroussi N, Benani M, Cambier Nappo E, Chartier Albrech C, Coicadan L, Condor R, D'Acremont G, D'Ovidio N, De Brito B, Deberdt P, Delatour A, Gorde-Grosjean S, Louvel M, Michot-Cottias A-S, Ravilly S, Seror E and Turberg-Romain C; Adjemian S, Auffroy 0, Begard M, Harant J, Mouaouya M, Receveau F and Sigere ML for technical assistance; Cuquemelle A for secretarial assistance; the Association Clinique et Thérapeutique Infantile du Val de Marne team: Ramay I, Prieur C; Prieur A, Borg M, Meyet L, Levy J and Zemmour E (Association Clinique et thérapeutique Infantile du Val de Marne); and the CRC team: Brussieux M and Hoffart C from the Clinical Reaserch Centre of the CHI Créteil.

Contributors RC, CL, NO, CJ, OL and EV designed the study. RC, CL, NO, CJ, OL, $A S, C B, A E, F C, F C-S, A W, O R$ and $E V$ analysed and interpreted the data and drafted the article. SB and CL performed the statistical analysis. EV, SA, NS, RC and MS-L performed the microbiological analysis. All authors revised and approved the manuscript.

Funding This work was supported by the French Ministry of Health DGOS PHRC regional IDF 2020 number AOR20095.

Competing interests $\mathrm{RC}, \mathrm{CL}$ and $\mathrm{EV}$ received personal fees and non-financial support from Pfizer. RC reports personal fees from Merck, GSK, Sanofi and AstraZeneca outside the submitted work. Conflicts that the editors consider relevant to the content of the manuscript have been disclosed.

Patient consent for publication Not required.

Ethics approval The study protocol was approved by an ethics committee (CPP IDF IX no. 08-022). Parents of all infants and children provided written informed consent. 
Provenance and peer review Not commissioned; externally peer reviewed.

Data availability statement Data are available upon reasonable request. Deidentified data available upon reasonable request after signed DTA.

Supplemental material This content has been supplied by the author(s). It has not been vetted by BMJ Publishing Group Limited (BMJ) and may not have been peer-reviewed. Any opinions or recommendations discussed are solely those of the author(s) and are not endorsed by BMJ. BMJ disclaims all liability and responsibility arising from any reliance placed on the content. Where the content includes any translated material, BMJ does not warrant the accuracy and reliability of the translations (including but not limited to local regulations, clinical guidelines, terminology, drug names and drug dosages), and is not responsible for any error and/or omissions arising from translation and adaptation or otherwise.

Open access This is an open access article distributed in accordance with the Creative Commons Attribution Non Commercial (CC BY-NC 4.0) license, which permits others to distribute, remix, adapt, build upon this work non-commercially, and license their derivative works on different terms, provided the original work is properly cited, appropriate credit is given, any changes made indicated, and the use is non-commercial. See: http://creativecommons.org/licenses/by-nc/4.0/.

ORCID iD

Corinne Levy http://orcid.org/0000-0002-1927-6360

\section{REFERENCES}

1 Castagnoli R, Votto M, Licari A, et al. Severe acute respiratory syndrome coronavirus 2 (SARS-CoV-2) infection in children and adolescents. JAMA Pediatr 2020;174:882.

2 Wu Z, McGoogan JM. Characteristics of and important lessons from the coronavirus disease 2019 (COVID-19) outbreak in China: summary of a report of 72314 cases from the Chinese center for disease control and prevention. JAMA 2020;323:1239-42.

3 Ludvigsson JF. Systematic review of COVID-19 in children shows milder cases and a better prognosis than adults. Acta Paediatr 2020;109:1088-95.

4 CDC COVID-19 Response Team. Coronavirus disease 2019 in children - United States, February 12-April 2, 2020. MMWR Morb Mortal Wkly Rep 2020;69:422-6.

5 Riphagen S, Gomez X, Gonzalez-Martinez C, et al. Hyperinflammatory shock in children during COVID-19 pandemic. Lancet 2020;395:1607-8.

6 Belot A, Antona D, Renolleau S, et al. SARS-CoV-2-related paediatric inflammatory multisystem syndrome, an epidemiological study, France, 1 March to 17 may 2020. Euro Surveill 2020;25.

7 Davies P, Evans C, Kanthimathinathan HK, et al. Intensive care admissions of children with paediatric inflammatory multisystem syndrome temporally associated with SARS-CoV-2 (PIMS-TS) in the UK: a multicentre observational study. Lancet Child Adolesc Health 2020;4:669-77.

8 Feldstein LR, Rose EB, Horwitz SM, et al. Multisystem inflammatory syndrome in U.S. children and adolescents. N Engl J Med 2020;383:334-46. doi:10.1056/NEJMoa2021680

9 Toubiana J, Poirault C, Corsia A, et al. Kawasaki-like multisystem inflammatory syndrome in children during the covid-19 pandemic in Paris, France: prospective observational study. BMJ 2020;369:m2094.

10 Verdoni L, Mazza A, Gervasoni A, et al. An outbreak of severe Kawasaki-like disease at the Italian epicentre of the SARS-CoV-2 epidemic: an observational cohort study. Lancet 2020;395:1771-8.

11 Dong Y, Mo X, Hu Y, et al. Epidemiology of COVID-19 among children in China. Pediatrics 2020;145:e20200702.

12 Tsang TK, Fang VJ, Chan K-H, et al. Individual correlates of infectivity of influenza A virus infections in households. PLoS One 2016;11:e0154418.

13 Eubank S, Eckstrand I, Lewis B, et al. Commentary on Ferguson, et al., "impact of non-pharmaceutical interventions (NPIs) to reduce COVID-19 mortality and healthcare demand". Bull Math Biol 2020;82:52. doi:10.1007/s11538-020-00726-x

14 Munro APS, Faust SN. Children are not COVID-19 super spreaders: time to go back to school. Arch Dis Child 2020;105:618-9. doi:10.1136/archdischild-2020-319474

15 Levy C. Changes in RT-PCR-positive SARS-CoV-2 rates in adults and children according to the epidemic stages. Pediatr Infect Dis $J$ 2020. doi:10.1101/2020.05.18.20098863
16 Jones TC, Mühlemann B, Veith T. An analysis of SARS-CoV-2 viral load by patient age, 2020. Available: https://zoonosencharitede/ fileadmin/user_upload/microsites/m_cc05/virologie-ccm/dateien_ upload/Weitere_Dateien/analysis-of-SARS-CoV-2-viral-load-bypatient-agepdf

17 L'Huillier AG, Torriani G, Pigny F, et al. Culture-Competent SARSCoV-2 in nasopharynx of symptomatic neonates, children, and adolescents. Emerg Infect Dis 2020;26:2494-7.

18 Zhu Y, Bloxham CJ, Hulme KD, et al. Children are unlikely to have been the primary source of household SARS-CoV-2 infections. medRxiv 2020.

19 Zhang J, Litvinova M, Liang Y, et al. Changes in contact patterns shape the dynamics of the COVID-19 outbreak in China. Science 2020;368:1481-6.

20 RIVM. The National Institute for public health and the environment (RVIM). children and COVID-19, 2020. Available: https://wwwrivmnl/ en/novel-coronavirus-covid-19/children-and-covid-19 [Accessed 7 May 2020].

21 Danis K, Epaulard O, Bénet T, et al. Cluster of coronavirus disease 2019 (COVID-19) in the French Alps, February 2020. Clin Infect Dis 2020;71:825-32.

22 Fontanet A, Grant R, Tondeur L. SARS-CoV-2 infection in primary schools in northern France: a retrospective cohort study in an area of high transmission, 2020. Available: https://wwwmedrxivorg/ content/101101/2020062520140178v2

23 Gudbjartsson DF, Helgason A, Jonsson H. Spread of SARS-CoV-2 in the Icelandic population. N Engl J Med2020. doi:10.1056/ NEJMoa2006100

24 Sethuraman N, Jeremiah SS, Ryo A. Interpreting diagnostic tests for SARS-CoV-2. JAMA 2020;323:2249.

25 Fontanet A, Tondeur L, Madec Y, et al. Cluster of COVID-19 in northern France: a retrospective closed cohort study. SSRN Journal 2020.

26 Levy C, Vie le Sage F, Varon E, et al. Pediatric ambulatory and hospital networks for surveillance and clinical epidemiology of community-acquired infections. J Pediatr 2018;194:269-70.

27 Gaborieau L, Delestrain C, Bensaid P, et al. Epidemiology and clinical presentation of children hospitalized with SARS-CoV-2 infection in suburbs of Paris. J Clin Med 2020;9. doi:10.3390/ jcm9072227. [Epub ahead of print: 14 Jul 2020].

28 Caducée.net. Covid-19: Paris area epidemiologic situation, 2020 Available: https://www.caducee.net/actualite-medicale/14774/covid19-la-situation-epidemiologique-en-ile-de-france.html

29 Li W, Zhang B, Lu J. The characteristics of household transmission of COVID-19. Clin Infect Dis 2020:ciaa450. doi:10.1093/cid/ciaa450

30 Somekh E, Gleyzer A, Heller E, et al. The role of children in the dynamics of intra family coronavirus 2019 spread in densely populated area. Pediatr Infect Dis J 2020;39:e202-4.

31 Mina MJ, Parker R, Larremore DB. Rethinking Covid-19 test sensitivity - a strategy for containment. $N$ Engl J Med 2020;383:e120.

32 Posfay-Barbe KM, Wagner N, Gauthey M, et al. COVID-19 in children and the dynamics of infection in families. Pediatrics 2020;146. doi:10.1542/peds.2020-1576. [Epub ahead of print: 26 May 2020].

33 Wölfel R, Corman VM, Guggemos W, et al. Virological assessment of hospitalized patients with COVID-2019. Nature 2020;581:465-9.

34 Bullard J, Dust K, Funk D, et al. Predicting infectious SARS-CoV-2 from diagnostic samples. Clin Infect Dis 2020. doi:10.1093/cid/ ciaa638. [Epub ahead of print: 22 May 2020].

35 Wu J, Huang Y, Tu C, et al. Household transmission of SARS-CoV-2, Zhuhai, China, 2020. Clin Infect Dis 2020;71:2099-108.

36 Sermet-Gaudelus I, Temmam S, Huon C. Prior infection by seasonal coronaviruses does not prevent SARS-CoV-2 infection and associated multisystem inflammatory syndrome in children, 2020. Available: https://wwwmedrxivorg/ content/101101/2020062920142596v1

37 Ouldali N, Cohen R, Levy C, et al. Pneumococcal susceptibility to antibiotics in carriage: a 17 year time series analysis of the adaptive evolution of non-vaccine emerging serotypes to a new selective pressure environment. J Antimicrob Chemother 2019;74:3077-86.

38 UNESCO. Adverse consequences of school closures, 2020. Available: https://en.unesco.org/covid19/educationresponse/ consequences

39 Davies NG, Klepac P, Liu Y, et al. Age-dependent effects in the transmission and control of COVID-19 epidemics. Nat Med 2020;26:1205-11. 